\title{
INNOVATION THROUGH A SELF-ORGANIZATION LENS
}

\author{
${ }^{1}$ Carmen Joham, ${ }^{2}$ Majharul Talukder and ${ }^{2}$ Mohammed Aseeri \\ ${ }^{1}$ School of Management, Division of Business, University of South Australia, Adelaide, Australia \\ ${ }^{2}$ Faculty of Business, Government and Law, University of Canberra, ACT 2617, Australia
}

Received 2014-07-08; Revised 2014-10-03; Accepted 2014-10-11

\begin{abstract}
This study argues that the concept of 'self-organization' is useful as an alternative to evaluate innovative capacity in rural communities and enable an effective engagement with the economic development regions. The concept of self-organization provides a means of reviewing regions in a manner which enables local Governments to measure and develop innovative capacity. Developing innovative capacity is seen as an important driver for achieving the targets of a country strategic planning agenda. This paper presents a study in the state of South Australia, Australia in which the self-organization concept offers a strategy for proactively engaging the regions to innovation.
\end{abstract}

Keywords: Self Organization, Innovation, Innovation Cluster, Social Networks, Knowledge Cluster, Social Development

\section{INTRODUCTION}

According to Plowman et al. (2003) recent research report on innovation in rural Queensland, some parts of rural Australia are struggling to adjust to ongoing socio-economic demands. Some towns and regions do well while others are still in decline often blaming the increased global competition reducing demand for traditional rural commodities. This paper presents a research aimed to study this problem in country South Australia. The Organization for Economic Cooperation and Development (OECD 2006) turned its attention to the local environment required to encourage sustainable regional economic development. A favored concept is that of innovative capacity where this is perceived to be a key ingredient for building locally generated, high performance communities (Fuchs, 2002). The innovative capacity theory that now dominates this literature usually draws on the knowledge sharing networks theories (Granovetter, 1973; Lawson, 1999; Stalk et al., 1992) on capability or on Creativity Indexes (Florida, 2003; 2005) with emphasis on tolerance of diversity (Rogers, 2003). However, alone, these networking theories of innovation do not provide Corresponding Author: Majharul Talukder, Faculty of Business, Government and Law, University of Canberra, ACT 2617, Australia very much detail on what sorts of networks are required, or why exactly they are innovative.

The concept of self-organization (Morgan, 1986; Camazine et al., 2001; Joham 2006; Metcalfe 2007) assumes innovation at a community level is dependent on the effectiveness of idea-sharing networks; how effectively differing disciplines (knowledge clusters) can share their ideas, problems and knowledge. The intent of the idea-sharing is to solve regional problems including the problem of taking advantage of opportunities. In response to hearing about a problem generated from one knowledge cluster, innovation requires other knowledge clusters to share solution ideas drawn from their own area of expertise (scientists, builders, medicos, engineers, farmers, designers, chemists etc.). For example, someone designing a machine to extract water from the atmosphere efficiently may need assistance from chemists to solve a design problem concerning low surface tension surfaces. Someone who normally operates within an engineering knowledge cluster may need to look for a way of communicating with the applied chemistry community. Sometimes, however, the cluster with the problem is not clear about which knowledge cluster might have an innovative solution. Idea sharing networks help overcome these constraints. 
Regions are seen as being made up of numerous, if disconnected, knowledge clusters, each with its discipline relevant expertise. Innovations typically require effective idea sharing between those knowledge clusters. In a recent research on social innovation networks conducted by Taatila et al. (2006), the need for strategies enabling effective idea discussion among social clusters is also supported. Their research brings to the fore that not only regional towns but countries like Finland and other European nations are in urgent need of an idea-sharing framework, in which social networks interaction are supported so that these countries can produce, support and sustain innovation. If the clusters have no way of idea sharing, then innovation is expected to be less than optimal. Conversely, if there is only one significant knowledge cluster, as may happen in traditional farming or manufacturing regions, then multidiscipline idea sharing will also be problematic. The Small-Worlds Network phenomenon (Watts, 1999a; 1999b; Killworth and Bernard, 1979; Buchanan, 2002) suggests the appropriate level of independence of knowledge clusters and appropriate level of idea sharing between discipline clusters for maximum innovation.

This study argues that the concept of 'selforganization' is useful to evaluate innovative capacity in rural communities and will begin with a brief overview of the four 'signatures' of self-organization required to be present in a region aiming for socio economic development. Figure 1 shows how certain competencies and the four signatures combine to characterize a selforganizing system of innovation (Beckett et al., 2002). These signatures highlight key social structures and major gaps in the innovative processes of a community applying an interpretative qualitative approach to score how concerned communities/people are on economic; score whether creativity is seen to be the main solution to their economic problems; score the facility for problem sharing and score the Small-Worlds weak-linked knowledge clusters.

A study will be presented as empirical example of self-organization for innovation through idea-sharing networks. For the model presented in Fig. 1, a management view has been used, with a focus on selforganization capacity as the basis of an assessment process. It is possible to represent innovation as a system and explore the deficiencies in that system using the four signatures of self-organization as the bases to analyze and conceptualize innovation. Through the application of the self-organizing system of innovation presented in Fig. 1, an assessment can be started by asking some key questions: Is there an adequate flow and understanding of prospective innovation activities? How important is innovation to their region? What mechanisms are used to discuss economic threats and opportunities in the region? What Knowledge is present and is needed in the region for prospective innovation?

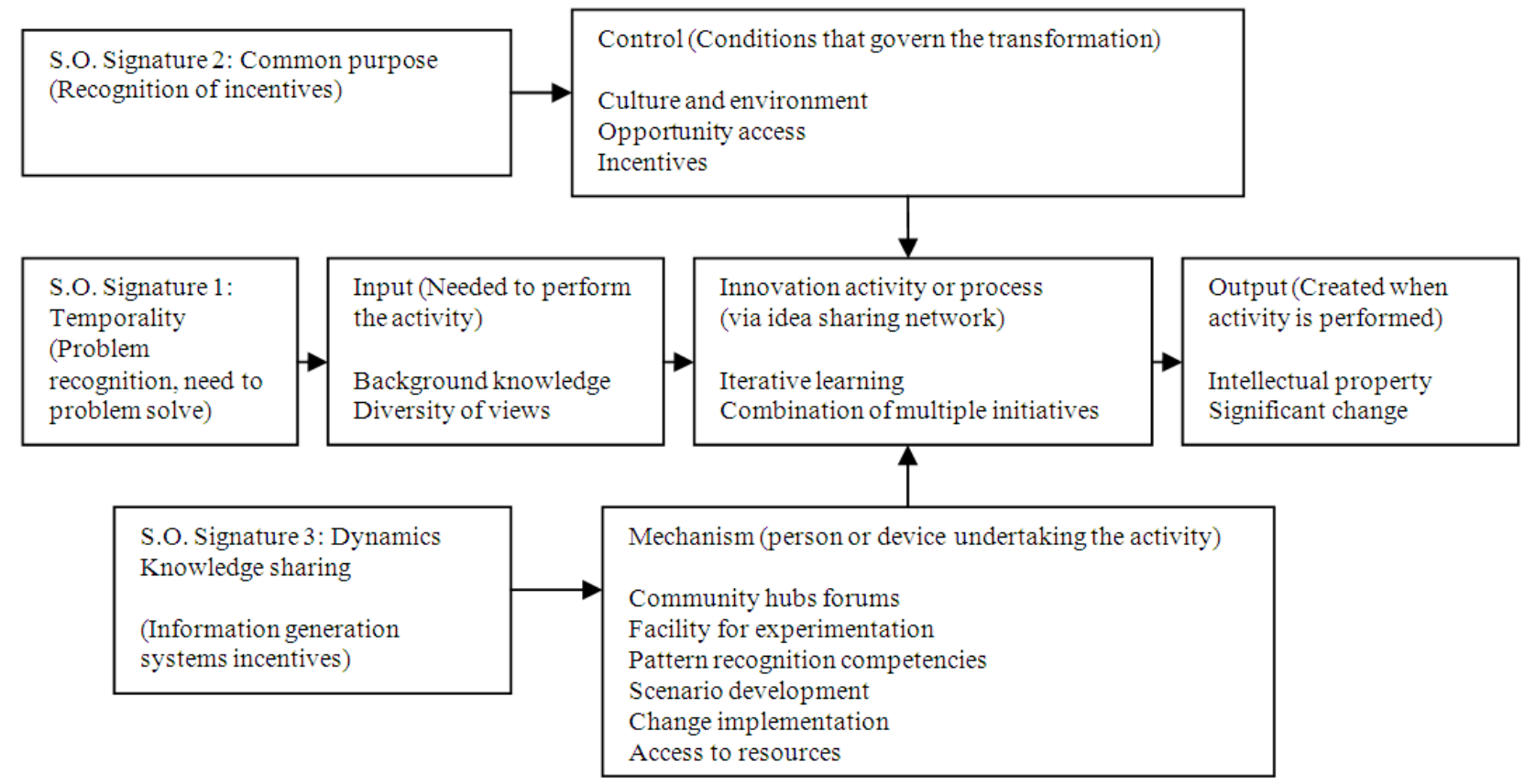

Fig. 1. Self-organization of innovation process (Beckett et al., 2002) 
The study strengthens the argument for effective idea sharing between communities' knowledge clusters for achieving innovation capacity.

\section{LITERATURE REVIEW AND THEORETICAL FRAMEWORK}

Understanding and integrating innovative practices into organizational strategy can be important for regions that want to differentiate itself. The innovation strategy should address culture, processes and enabling technology in a holistic way. Organization's Innovation Management Framework is designed to help companies develop a comprehensive, integrated approach to implement and support an innovation management strategy. This framework is repeatable reference architecture for innovation and is intended to allow organizations to share and learn about innovation management best practices and enabling technologies as a starting point for strategic debates for their innovation management strategy (Lehtonen et al., 2005).

Rogers (2003) defines "innovation as an idea, practice or object that is perceived as new by an individual or other unit of adoption. If an idea or object seems new to the individual, it is considered as an innovation". Furthermore, according to Rogers (2003), "the concept of newness in an innovation need not just involve new knowledge. An individual may have known of an innovation for sometime but not yet developed a favorable or unfavorable attitude toward it". He argues that "the newness aspect of an innovation can be expressed in terms of knowledge, persuasion or a decision to adopt" (Rogers, 2003).

Afuah (2003) states that innovation is the use of a new technological system that offers a better and improved service. The outcome of the new system is more efficiency and that it is new to the employees. According to Higgins (1995), "innovation is the development of something new that has significant value to an individual, a group, an organization, an industry or a society". This definition explains that an innovation is something-an object or a system-that has significant value to individuals or to organizations. Organizations intend that individual employees will adopt an innovation which consequently will enhance work efficiency, gain competitive advantage and maintain superior management systems (Talukder, 2011). Holt (1983) makes similar claims that innovation is a process, which uses knowledge and information to create or introduce something that is new and useful to individuals or to organizations.
According to Zaltman et al. (1973), "innovation can be defined as an idea, practice, or material artifact perceived to be new by the relevant unit of adoption". They argued that innovation is any new system or program, which is new to individuals or organizations who adopting it no matter how old the system may be or how many other organizations may have adopted it. The length of time the system has been in existence and the number of other organizations that have adopted it does not directly affect its newness to the organization or to the individuals considering its adoption (Zaltman et al., 1973). They state that "this does not imply that each new idea or system or technology adopted by an organization is necessarily new to society. A particular new technology may be new only to an organization or to individuals who are adopting it" (1973). The idea is also supported by Rogers (2003). The key point in this definition is that any technology or system is considered an innovation if it is new to the individual who plans to adopt it even though the technology has been in existence for a long time.

Joham (2006) argues that idea sharing networks will self-organize innovative solutions to regional problems if the four 'signatures' of self-organization are present in a region. Very briefly, self-organization is defined as the ability of a non-centralized system to emerge a strategic response to a change in its environment and it only occurs in systems where multiple interactions among individuals are possible (Camazine et al., 2001; Kauffman, 1993; 1995; Jumaire, 1995; Joham, 2006). Self-organization is a complex and dynamic process that can automatically arise when changes or the need for a change occurs. In most cases, it is an innovative and creative response from knowledge clusters and/or individuals to address a problem impacting the entire system. The four signatures of self-organization are listed below. After determining if these signatures are present in appropriate form, those interested in regional development can decide if they wish to redesign the idea sharing networks to emerge any missing signatures (Talukder, 2014).

\section{Signature 1: Temporality}

For self-organization to occur the community must feel there is a problem in need of a solution and that the problem is getting worse. Self-organization needs time to occur, but also there needs to be some sense of urgency. The establishment of a common understanding of what is going on and what might be done about it takes time to establish. Yet, self- 
organization creates the system's capacity for structure formation; process communication and multiple interactions by mutual adjustment in behavior based on a community shared of 'urgency and action-time'. The proposed measure for this signature is the assessment of the participant's description and evaluation of present, past and future levels of economic activity in the region; seeking good news and bad news stories. From the analysis of the responses, it should be possible to provide a score of how concerned participants are about the economy.

\section{Signature 2: Common Purpose and Recognition of Constraints}

For self-organization to occur, the community must feel the solution to their economic problems is creativity leading to innovation. Camazine et al. (2001) assert that self-organization starts from a positive feedback event where some problematic phenomenon grows exponentially. There is a significant cue to act. All those involved develop a sense of common purpose, a common concern or putting it in other words, an overall vision of what is going on. The proposed key measure for this signature is the assessment of the participant's view of innovation in the region and their understanding of innovation and creativity as opposed to normal progress. From this it should be possible to score whether creativity is seen to be the main solution to their economic problems.

\section{Signature 3: Dynamic Knowledge (Problem) Sharing}

For self-organization to occur there must be a system of dynamic knowledge/problem sharing. As Fuchs (2003) points out "all self-organizing systems are information-generating systems" but there needs to be more than information sharing. There needs to be a capacity to generate ideas to solve problems (Weick, 2006; Reagans and McEvily, 2003). The problems and what may be their appropriate solutions, are dynamic. What may have worked at one point in time may well not work later. Information, even if correct previously, quickly goes out of date. Effective, up-to-date, idea generation through information sharing appears to be not only essential, but to be part of the motivations for the emergence of new structures. The proposed key measures align with this signature are focus on how the region discusses economic threats and opportunities, particularly when and in what public forums (e.g., newspapers, specific local radio shows, public meetings, investment or innovation clubs). If a local business had some problem it needed help with solving, then how would it go about seeking appropriate knowledge? Where do they go to share notional ideas? Are these nodes of idea sharing well networked together (see SmallWorlds Network statistics). From this, it should be possible to score the facility for problem sharing.

\section{Signature 4: Linked Knowledge Clusters (Small- Worlds)}

For self-organization to occur there needs to be a recognition of Small-Worlds weak-linked knowledge clusters, each able to bring different expertise to solving problems. Camazine et al. (2001; Joham, 2006) assert that in a good number of cases we simply imitate those we interact with, perhaps more so with friends and family, those we know and trust, our closest neighbors. We tend to do as they do, imitate their behavior. This generates, behavior norms which leads to a co-operative cluster involving our immediate neighbors. Discipline clusters as well as social groups display this behavior. Even competition with our nearest can be considered a co-operative process, normalizing the behavior of our immediate influence cluster from its past experiences. Comfort (1994:3) explains: “...Voluntary selection allows individuals operating within organizational systems to cluster around points of energy that they find more attractive, creating a "peak" of energy distribution over repeated interactions and aligning other members to that point in a "basin" of attraction".

So, within a larger system, sub systems or clusters (small-worlds networks) are expected to emerge, rather than a set of individuals or a 'everyone is equally influenced by everyone" homogeneous system. These clusters (communities of practice) create a non-centralized information sharing system and could be measured by the existence of a good representation of various professions (engineers, doctors, lawyers, teachers, public servants, graduates etc.) in the community, the region communication infrastructure and global connectivity.

These four signatures are summarized with examples in Table 1. However, it will be realized that these signatures suggest that once a region is triggered into thinking innovation is the solution to their concerns then the presence of effective idea sharing networks becomes the key to their effectively selforganizing for that innovation. 
Table 1. Self-organization-reasoning and examples

\begin{tabular}{|c|c|c|c|c|c|}
\hline Signature & Question & Reasoning & Measurement & Example 1 & Example 2 \\
\hline Temporal & $\begin{array}{l}\text { Is there an increasing } \\
\text { feeling that there is a } \\
\text { common challenge that } \\
\text { needs to be addressed? }\end{array}$ & $\begin{array}{l}\text { "Necessity is the } \\
\text { mother of innovation". }\end{array}$ & $\begin{array}{l}\text { Number of people } \\
\text { who think there is a } \\
\text { challenge that is } \\
\text { growing significantly. }\end{array}$ & $\begin{array}{l}\text { There may be a feeling } \\
\text { that the Arts Festival is } \\
\text { no longer presenting } \\
\text { novel events. }\end{array}$ & $\begin{array}{l}\text { Most engineers feel } \\
\text { a need to move to the } \\
\text { design end of the } \\
\text { manufacturing supply chain } \\
\text { in this region. }\end{array}$ \\
\hline $\begin{array}{l}\text { Common } \\
\text { purpose }\end{array}$ & $\begin{array}{l}\text { Is there a feeling } \\
\text { that creativity is the } \\
\text { solution to the } \\
\text { challenge? }\end{array}$ & $\begin{array}{l}\text { A sense of common } \\
\text { purpose invokes } \\
\text { groups(herd) effects } \\
\text { of motivation. }\end{array}$ & $\begin{array}{l}\text { Number of people } \\
\text { who think creativity } \\
\text { is the solution to the } \\
\text { challenge identified } \\
\text { above. }\end{array}$ & $\begin{array}{l}\text { Most agree more } \\
\text { creativity is needed. }\end{array}$ & $\begin{array}{l}\text { It is commonly agreed } \\
\text { that design is about creative } \\
\text { problem solving. }\end{array}$ \\
\hline $\begin{array}{l}\text { Dynamic } \\
\text { knowledge } \\
\text { sharing }\end{array}$ & $\begin{array}{l}\text { Are there adequate } \\
\text { opportunities for } \\
\text { responses to the } \\
\text { challenge to be rapidly } \\
\text { shared by a wide range } \\
\text { of specialists in the } \\
\text { wider community? }\end{array}$ & $\begin{array}{l}\text { Rich, dynamic, } \\
\text { knowledge sharing } \\
\text { between people with } \\
\text { very different } \\
\text { expertise is required } \\
\text { for creativity. }\end{array}$ & $\begin{array}{l}\text { Small-Worlds ideas } \\
\text { sharing network } \\
\text { statistics. } \\
\text { Network = where do } \\
\text { you go to discuss } \\
\text { notional ideas? }\end{array}$ & $\begin{array}{l}\text { A restaurant acts as a } \\
\text { common meeting place } \\
\text { where the challenge can } \\
\text { be discussed with a wide } \\
\text { range of experts, on an } \\
\text { ongoing daily basis. }\end{array}$ & $\begin{array}{l}\text { A design center is set up } \\
\text { which provides office space } \\
\text { to design projects which are } \\
\text { supervised by task groups } \\
\text { made up of experts from a } \\
\text { wide range of disciplines, } \\
\text { open to public debate. }\end{array}$ \\
\hline $\begin{array}{l}\text { Tied } \\
\text { knowledge } \\
\text { clusters }\end{array}$ & $\begin{array}{l}\text { Are the areas of } \\
\text { expertise (eg. arts, } \\
\text { engineering, medical, } \\
\text { legal, social etc.) well } \\
\text { linked? }\end{array}$ & $\begin{array}{l}\text { Experts, faced with } \\
\text { the limits to their } \\
\text { knowledge, need to } \\
\text { know who to talk to } \\
\text { next. }\end{array}$ & $\begin{array}{l}\text { The number of people } \\
\text { who think there are } \\
\text { the same three or four } \\
\text { places to go to discuss } \\
\text { ideas with a } \\
\text { multidisciplinary } \\
\text { audience. }\end{array}$ & $\begin{array}{l}\text { Artists' idea sharing } \\
\text { locations are well linked } \\
\text { to engineers, lawyers, } \\
\text { builders, materials } \\
\text { experts, IT specialist etc. } \\
\text { idea sharing locations. }\end{array}$ & $\begin{array}{l}\text { Engineers get access to } \\
\text { artists, chemists, transport, } \\
\text { overseas etc. idea sharing } \\
\text { locations. }\end{array}$ \\
\hline
\end{tabular}

\section{METHODOLOGY}

To begin the process of testing the idea that the concept of self-organization might be used to engage with and develop a region, a study was devised. Australian Bureau of Statistics (ABS) data on innovative towns was used to identify a reasonably independent region within South Australia (SA). The stand out example was Mt Gambier, reported by the ABS as the most innovative town in SA.

The first prediction made using the concept of selforganizing was that this town would also score highly with the ABS as being 'collaborative'; that is open to idea sharing. This was found to be so, as validated by current informal ABS reports and member of the South Australian Strategic Planning board.

The next prediction was that that this town would have presented the four signatures of self-organization including good facilities for idea sharing. These signatures have been operationalized into particular research questions and listed in Table 2 . To test this we interviewed forty-three local business persons from different industries and backgrounds in the town. First it was found necessary to identify relevant small business persons to act as participants and learn how they defined and reacted to the term 'innovation'.

Emails were used to set up interviews. The first email was limited to introducing the purpose of the project and requesting an initial interview. The target audiences were selected randomly from prior analyses of the following documents: The Mount Gambier's Innovation Award archive, ABS Professionals regional statistic database and businesses or people cited repeatedly in the local newspaper (i.e., The Border Watch). The newspaper was monitored over a period of four months prior to sending the first email. The selected audience consisted of (a) the public service industry, (b) local community members and (c) businesses which received a local innovation award. Our main concern was to ensure the participation of relevant people, particularly business people who were local to the region and who had a certain degree of community participation.

Once participants confirmed, their interest a second email was sent. The content of this email addressed two main issues; their view on innovation and their perception on Mount Gambier as likely 'number one' innovative region in SA. Next, two researchers undertook a two week visit to the region during which personal interviews, familiarization with local public documents, cold-call interviews with retail outlets and a focus group session took place. On average, the interviews, which were pre-planned to last an hour, took 2 to $3 \mathrm{~h}$ due to participants' enthusiasm. Most interviews, except for the cold-call on retail outlets, were conducted in a local coffee shop. The focus group, likewise, ran for approximately $4 \mathrm{~h}$. 
Table 2. Self organization questions to access innovation capability

\begin{tabular}{|c|c|}
\hline Self-organization signature & Innovation capability rural S.A \\
\hline Temporal & $\begin{array}{l}\text { Asking participants to describe and evaluate: } \\
\text { The present levels of economic activity in the region; seeking good news and bad news stories }\end{array}$ \\
\hline $\begin{array}{l}\text { From the analysis of their responses we } \\
\text { were able to provide a score of how } \\
\text { concerned they are about the economy. }\end{array}$ & $\begin{array}{l}\text { The resent past levels of economic activity in the region; seeking good news and bad news stories } \\
\text { The future levels of economic activity in the region; seeking good news and bad news stories }\end{array}$ \\
\hline $\begin{array}{l}\text { Common purpose and } \\
\text { recognition of constraints }\end{array}$ & $\begin{array}{l}\text { Asking participants to provide stories of innovation going on in the region; at present and } \\
\text { in the recent past: } \\
\text { What do they understand by innovation and creativity as opposed to normal progress? }\end{array}$ \\
\hline $\begin{array}{l}\text { From this, we were able to score } \\
\text { whether creativity and innovation } \\
\text { per se are seen to be the main } \\
\text { solution to their economic problems. }\end{array}$ & $\begin{array}{l}\text { How important is innovation and creativity to the region? Is it the single most important } \\
\text { requirement to improve the economy? } \\
\text { What is stopping innovation? }\end{array}$ \\
\hline Dynamic knowledge sharing & $\begin{array}{l}\text { Asking participants: } \\
\text { How does the region discuss economic threats and opportunities and in what public forums } \\
\text { (e.g., newspapers, specific local radio shows, public meetings, investment or innovation } \\
\text { clubs)? How often? }\end{array}$ \\
\hline $\begin{array}{l}\text { From this, we were able to score } \\
\text { the facility for problem sharing }\end{array}$ & $\begin{array}{l}\text { If a local business had some problem it needed help with solving, then how would it go about } \\
\text { seeking appropriate knowledge? Where do they go to share notional ideas? Are these nodes of } \\
\text { idea sharing well networked together (see Small-Worlds Network statistics). }\end{array}$ \\
\hline Linked knowledge clusters & $\begin{array}{l}\text { Asking participants: } \\
\text { Is there a good representation of the professions (engineers, doctors, lawyers, teachers, public } \\
\text { servants, graduates etc) in the region? }\end{array}$ \\
\hline $\begin{array}{l}\text { From this we were able to get some } \\
\text { measure of how networked they are. }\end{array}$ & $\begin{array}{l}\text { How good is the internet/phone/fax connection in the region? } \\
\text { How much interstate travel goes on? } \\
\text { How many long stay (over one month) business people visitors do you get per year? } \\
\text { How many international businesses are there in the region? } \\
\text { Is there a wide range of people from different countries living here and are they well represented } \\
\text { on the local committees and media? } \\
\text { Is there a lot of civic job rotation (council, development boards, water boards, religious and sport } \\
\text { clubs etc.)? }\end{array}$ \\
\hline
\end{tabular}

All interviews and the focus group were guided by the four signatures discussed above, yet all participants were given the opportunity to openly discuss any issues they considered necessary at any point of the interview. Attention was given to identifying existing community links, to the process in which business ideas were discussed in the region and to the particular participants' intangible knowledge of local places that supported idea sharing. Stories and narratives of what has and hasn't worked, in terms of infrastructures for developing an innovative environment, were collected. Some local businesses were also visited as a result of introductions from the interviews and focus groups to widen the number of participants.

\section{FINDINGS AND DISCUSSION}

It was found that Mt Gambier had all four signatures present. The rural downturn seemed to be the trigger for people to decide that something needed to be done. Those interviewed clearly understood and saw innovation as important for the town. There was little problem explaining what was meant by innovation and that everyone should be involved. So, the next self-organization signature was about the effectiveness of their idea sharing networks. From the interviews and focus group, among other things, it was possible to draft a network of the idea sharing locations. Figure 2. This shows as nodes where interviewees said they went to discuss notional innovative ideas. The lines between the nodes indicate that someone said they went to more than one location. For example, the line between the swimming center (top left) and the skilled migration program indicated that someone said they go to both these locations. This means that an idea mentioned in one location could easily be carried to the second location. Ideas were grouped under three themes: (a) Nature (b) recognition and (c) hub of ideas. Each theme had a subset of 30 open ended questions. Answers to these questions were coded and qualitative interpreted with the self-organizing system of innovation (Fig. 1).

The idea sharing network provides some insight into where ideas are shared and how different groups 
can get to share or advice about ideas raised in any one location. It goes some way to indicate the social life of innovative ideas in the town.

The network provides input to determining the role of government in a bottom up approach to regional innovation. Having identified the idea sharing network, it can be measured for how close it comes to conforming to the ideal of a Small-Worlds Network. Above, it was suggested this was the theoretical optimum structure for ideas to be well shared by a community. The metrics recommended to identify Small-World-ness are:

- A small 'average shortest path' (minimum = 1) and

- A large clustering coefficient $(\max =1)$

For this partial Mt Gambier network, the metrics are 2.4 and 0.4 respectively, which suggests that, while reasonable, there is room for improvement. This can be seen in the graph in Fig. 2 by suggesting the nodes around the edge of the graph could be more directly linked to each other. For example if the local radio organized regular innovative idea sharing sessions with people who attended the swimming club, Center link, the children's playgroup, the food market and the volunteers group then ideas would have more chance to influence a wider range of people.

The idea sharing network as shown in Fig. 2 is also useful in appreciating the centrality and effectiveness of certain locations or events. The City Council's open forums and the local newspaper articles appear to play a central role even though both are very different in how they act to share ideas. The Town Hall provides resources to encourage a forum for ideas to be aired before an experienced panel. The newspaper publishes articles airing ideas. The Farmers Market and the shop 'Stand Like Stone' were also important as ad hoc locations for talking to people in an informal atmosphere. These locations and events are being identified by local business people as where they liked to go and what they found useful. It is thought that this forms the basis of adding further events for idea sharing in the community.

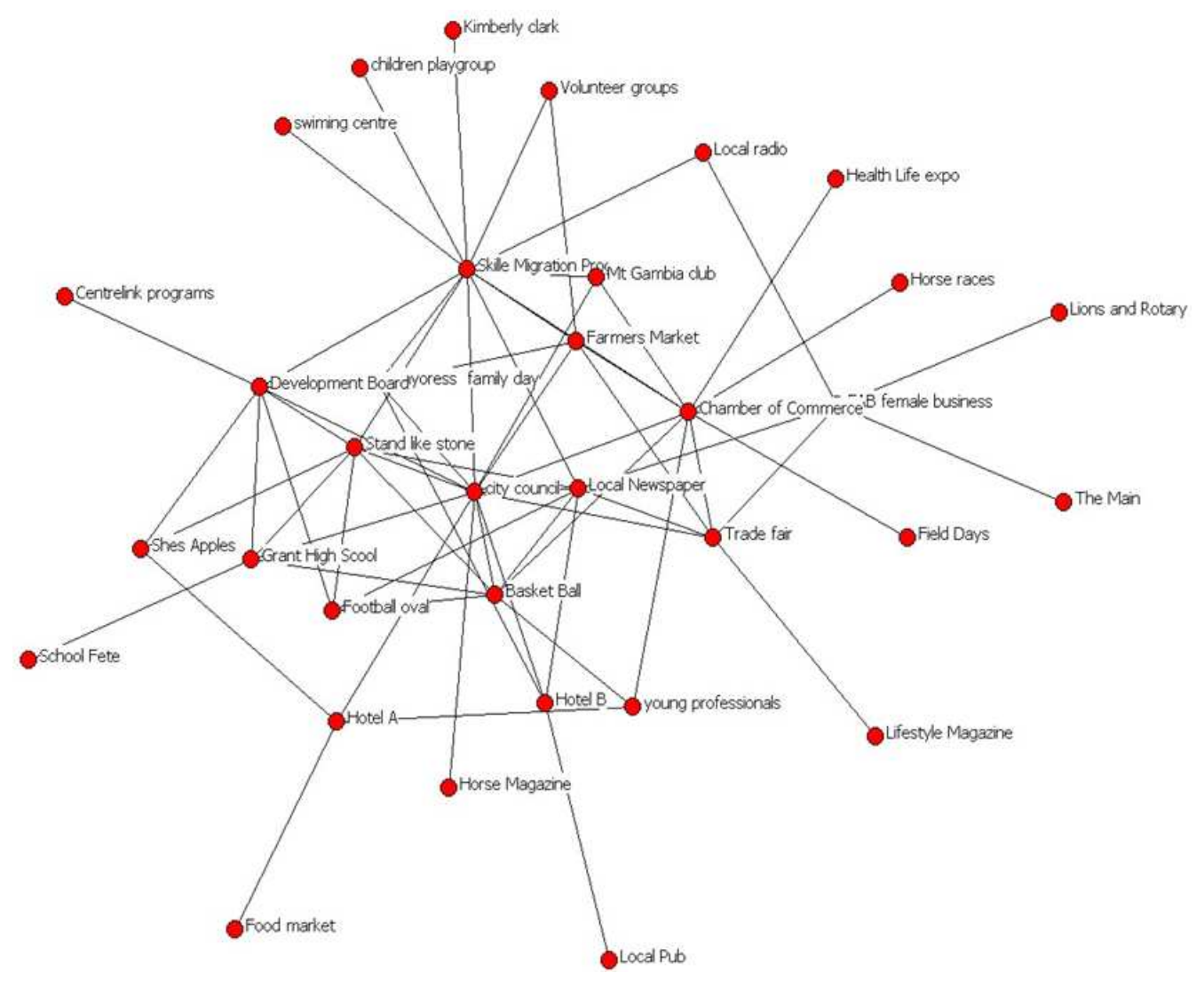

Fig. 2. Mt Gambier partial idea-sharing network 
A second emergent finding from the research was that three groups of business people were identified. These can be summarized by their thoughts:

- I could do something about this idea. Should I?

- This is an important idea! I need some help to deal with it

- I know a lot about this. I wonder if it is important for me to share it. Where should I go?

The first needs motivation perhaps in terms of copying others, the second is confused about where to go, as is the third but these people wish to tell something innovative they know. These groups provide input for how idea sharing forums might be designed.

A third emergent finding from the research was that 'developing innovative capacity' was seen as an important driver for achieving the targets of the South Australian Strategic Plan in all of its themes (i.e., prosperity, wellbeing, sustainability, communities and opportunities) and not only for the Creativity theme. The various responses and issues raised by the participants' view on innovation converged into seven comparable concepts. This includes: Networking, community network, sustainability, collaboration, creativity, local investment and development.

\section{CONCLUSION}

This study has argued that the concept of selforganization might be useful for engaging with regions. The role of Government is seen as assisting regional businesses to self-organize innovative ideas which include how to implement those ideas effectively. It has been suggested how innovation as idea sharing might be identified, measured and managed. In a paper of this length, it is only possible to give some indication of this approach to developing regional innovation. We recognized that there is a need for further research to suggest an optimum structure and strategies for ideas to be well shared by a community. The reliability of the theory in generation can further be improved by making similar studies in other locations. For that reason, we are currently conducting two other studies within the South Australian region (i.e., Port Lincoln and Berri). We aim to build up on this research and provide some insight from these comparative studies.

\section{REFERENCES}

Afuah, A., 2003. Innovation Management: Strategies, Implementation and Profits. 1st Edn., Oxford University Press, New York, ISBN-10: 0195142306, pp: 390.

Beckett, R.C., P.W.B. Hyland and C. Soosay, 2002. Representing enterprise innovation: A system engineering view. Proceedings of the 6th International Research Conference on Quality, Innovation and Knowledge Management, Feb. 1720, Kuala Lumpur, Malaysia.

Buchanan, M., 2002. Nexus: Small Worlds and the Groundbreaking Science of Networks. 1st Edn., W.W. Norton, New York, ISBN-10: 0393041530, pp: 235.

Camazine, S.S., J.L. Deneubourg and N.R. Franks, 2001. Self-Organization in Biological Systems. 1st Edn., Princeton University Press, ISBN-10: 0691012113.

Florida, R., 2003. The Rise of the Creative Class: And How it's Transforming Work, Leisure, Community and Everyday Life. 1st Edn., Hazard Press, Christchurch, ISBN-10: 1877270571, pp: 404.

Florida, R., 2005. The Flight of the Creative Class: The New Global Competition for Talent. 1st Edn., HarperCollins, New York, ISBN-10: $006075690 X$, pp: 326.

Fuchs, C., 2002. Some implications of Anthony Giddens' works for a theory of social selforganization. Emergence, 4: 7-35. DOI: 10.1207/S15327000EM0403-03

Fuchs, C., 2003. Co-operation and self-organization. TripleC, 1: 1-52.

Granovetter, M., 1973. The strength of weak ties. Am. J. Sociol., 78: 1360-1380.

Higgins, J., 1995. Innovate or evaporate. Futurist, 29: 42-49.

Holt, K., 1983. Product Innovation Management: Workbook for Management in Industry. 1st Edn., Butterworths, Boston, ISBN-10: 0408014415, pp: 312.

Joham, C., 2006. Self organization and comprehension of C\&IT policy. PhD Thesis, University of South Australia.

Jumaire, G., 1995. Self-organization via the creation of constraints: An information theoretic approach. Kybernetes, 24: 35-48. DOI: 10.1108/03684929510101821

Kauffman, S.A., 1993. The Origins of Order: SelfOrganization and Selection in Evolution. 1st Edn., Oxford University Press, New York, ISBN-10: 0195079515, pp: 709. 
Kauffman, S.A., 1995. At Home in the Universe: The Search for Laws of Self-Organization and Complexity. 1st Edn., Oxford University Press, New York, ISBN-10: 0195095995, pp: 321.

Killworth, P. and H. Bernard, 1979. A pseudomodel of the small world problem. Soc. Forces, 58: 477-505. DOI: $10.1093 / \mathrm{sf} / 58.2 .477$

Lawson, C., 1999. Towards a competence theory of the region, Cambridge J. Econom., 23: 151-166. DOI: $10.1093 / \mathrm{cje} / 23.2 .151$

Lehtonen, T., J. Jaentti and M. Nymark, 2005. Customer loyalty card and devices associated therewith. US Patent.

Metcalfe, M., 2007. Pragmatic inquiry. J. Operat. Res. Society Forthcom.

Morgan, G., 1986. Images of Organization. 1st Edn., Sage Publications, Beverly Hills, ISBN-10: 0803928300, pp: 368.

OECD, 2006. Organization for economic cooperation and development.

Plowman, I., N.M. Ashkanasy and J. Gardner, 2003. Innovation in rural queensland: Why some towns prosper while others languish. University of Queensland and Queensland Department of Primary Industries, Brisbane.

Reagans, R. and B. McEvily, 2003. Network structure and knowledge transfer: The effects of cohesion and range. Admin. Sci. Q., 48: 240-267. DOI: $10.2307 / 3556658$
Rogers, E., 2003. Diffusion of Innovations. 5th Edn., Free Press, New York, ISBN-10: 0743222091, pp: 576.

Stalk, G., P. Evans and L.E. Sgulman, 1992. Competing on capabilities. Harvard Bus. Rev., 70: 57-69. PMID: 10117369

Taatila, V., J. Suomala, R. Siltala and S. Keskien, 2006. Framework to study the social innovation networks. Eur. J. Innovat., 9: 312-326. DOI: $10.1108 / 14601060610678176$

Talukder, M., 2011. Development of an enhanced model of innovation adoption by individual employees. J. Asia Pacific Bus., 12: 316-339. DOI: 10.1080/10599231.2011.591691

Talukder, M., 2014. Managing Innovation Adoption: From Innovation to Implementation. 1st Edn., Gower Farnham, ISBN-10: 1472413377, pp: 226.

Watts, D., 1999a. Networks, dynamics and the small-world phenomenon. Am. J. Sociol., 105: 493527. DOI: $10.1086 / 210318$

Watts, D.J., 1999b. Small worlds. Princeton University Press.

Weick, K.E., 2006. Faith, evidence and action: Better guesses in an unknowable world. Organiz. Stud., 27: 1723-1736. DOI: 10.1177/0170840606068351

Zaltman, G., R. Duncan and J. Holbek, 1973. Innovations and Organizations. 99th Edn., Wiley, New York, ISBN-10: 047198129X, pp: 212. 